\title{
NILAI-NILAI HOLISTIK DALAM KAUNSELING ISLAM
}

\author{
Khairunnas Rajab \\ Fakulti Tarbiyah dan Keguruan. Universitas Islam Negeri \\ Suska. Riau. Indonesia. \\ Emel: khairunnasrajab@gmail.com
}

\begin{abstract}
Khulasah
Kaunseling Islam adalah sebuah paradigma yang menjelaskan nilai-nilai holistik Islam dalam khidmat dan bantuan terhadap klien, sebagai teoretikalpraktikal yang menjadi alternatif penyelesaian terhadap masalah berkenaan kepentingan kesihatan umat manusia. Kaunseling Islam adalah suatu bentuk ilmu berasaskan Islam di bidang Kaunseling Psikologi, di mana ia menghuraikan aspek emosi spiritual intuitif yang lengkap. Sejak awal lagi, apabila Nabi Muhammad SAW menyampaikan risalah kenabian, baginda telahpun mencorak dan mewarnai bidang kaunseling melalui nasihat dan tunjuk ajar terhadap masalah yang dihadapi umat Islam pada masa itu. Pada dekad ini, kaunseling Islam telah menjadi salah satu kajian yang diberi tumpuan dalam Islamisasi ilmu pengetahuan, sebagai usaha mengintegrasikan sains dengan Islam. Kaunseling Islam boleh dinyatakan sebagai khidmat dan bantuan bagi klien yang menghadapi masalah psikologi dengan menggunakan model khidmat dan bantuan kaunseling Islam yang sistematik. Kaunseling Islam menawarkan intergrasi kerohanian yang merangkumi keimanan, ketakwaan, keihsanan, istiqamah, kejujuran, keseimbangan, dan keterbukaan yang merupakan asas-asas penting dalam proses kaunseling. Artikel ini bertujuan menghuraikan teoretikal-praktikal kaunseling Islam yang boleh ditawarkan sebagai alternatif bagi menyelesaikan
\end{abstract}


masalah sosial psikologikal umat Islam di abad moden.

Kata Kunci: Kaunseling Islam, Kaunseling Barat, Iman, Ibadah, dan Ihsan

\begin{abstract}
Islamic counselling is a paradigm describes the holistic values of Islam in the services and assistance to clients, and as a theoretical-practical alternative solution to the problems concerned with human health interests. Islamic counselling is a form of knowledge based on Islam in the discipline of Counselling Psychology, in which it portrays the comprehensive aspects of emotional spiritual intuitive. From the beginning, when the Prophet Muhammad p.b.u.h delivered the message of prophecy, he was shaping and colouring the fields of counselling through advice and guidance on issues affecting the Muslim community at the time. In this decade, Islamic counselling has become one of the research focuses in the Islamization of sciences, as efforts to integrate science with Islam. Islamic counselling can be expressed as the services and assistance for clients who are suffering from psychological problems by using the services and assistance of systematic Islamic counselling. Integration of spiritual aspect has been offered by Islamic counselling that includes faith, piety, ihsan, consistency, honesty, balance and openness that are the foundations in the process of counselling. This article aims to explain the theoretical-practical Islamic counselling that can be proposed as an alternative in solving social psychological problems of Muslims in the modern century.
\end{abstract}

Keywords: Islamic Counselling, Western Counselling, faith, worships, Ihsan.

\title{
Pendahuluan
}

Islam adalah agama $k \bar{a} f f a h$ yang menjadi panduan bagi melayari kehidupan, mengawal umat supaya sentiasa 
berada dalam kebaikan dan menjauhi perkara keburukan yang boleh mendatangkan dosa dan maksiat. Kandungan ajaran Islam yang sistematik telah menjadikannya mudah untuk difahami sehingga umat manusia boleh melaksanakannya sebaik mungkin. Ajaran Islam menyentuh pelbagai dimensi kehidupan, sama ada di dunia mahupun di akhirat. Islam bukan sahaja untuk bertauhid, beribadah, dan berakhlak, malah Islam adalah sebuah agama yang mensejahterakan manusia secara lahir dan batin. Islam juga agama yang menekankan hal spiritual yang mensinergikan aspek fizikal dan psikologikal. Apabila Islam adalah agama yang lengkap, maka Islam boleh dipandang sebagai sumber ilmu pengetahuan yang sistematik dan rasional. ${ }^{1}$

Islam sebagai agama yang lengkap turut memberikan ruang yang selesa bagi membangun ilmu pengetahuan. Intelektual muslim di beberapa dekad terakhir berupaya mewujudkan sebuah bentuk nyata integrasi pengetahuan dengan nilai-nilai Islam. Islamisasi ilmu pengetahuan adalah tawaran yang tidak boleh diabaikan begitu sahaja. Intelektual muslim seperti Ismail Raji al-Faruqy, Seyyed Hossein Nasr dan Syed Muhammad Naquib al-Attas adalah pakar yang berjasa yang menggalakkan Islamisasi ilmu pengetahuan.

Pemikiran-pemikiran mengenai Islamisasi ilmu pengetahuan, dewesternisasi pengetahuan, atau gerakan seperti Assosiation of Muslim Social Scientist di Amerika merupakan petunjuk terhadap usaha-usaha mengintergrasikan nilai agama dengan sains yang perlu diterajui. $^{2}$ Kajian Islamisasi ilmu pengetahuan pada beberapa dekad terakhir ini, menunjukkan kemunculan kajian-kajian optimistik daripada para pakar psikologi

1 M. Quraish Shihab, Membumikan al-Qur'an, Fungsi dan Peran Wahyu dalam Kehidupan Masyarakat (Bandung: Mizan, 1993), 32.

2 Hanna Djumhana Bastaman, Integrasi Psikologi dengan Islam, Menuju Psikologi Islami (Yogyakarta: Pustaka Pelajar, 1997), 31. 
Muslim bagi mewujudkan psikologi Islam, psikoterapi Islam, kaunseling Islam dan kesihatan mental Islam. Pakar pengetahuan dalam kajian khusus ini turut melibatkan nama-nama seperti Muhammad Uthman Najati dan Malik B. Badri. Karya-karya berkenaan dengan kajian ini adalah seperti al-Qur'ān wa 'Ilm al-Nafs, Hadith al-Nabawiyyah wa 'Ilm al-Nafs, The Dilemma Moslem Psychologist, Methodhology Islamic Psychotherapy, Islam and Modern Psychotherapy dan Islamic Counseling.

Perkembangan teknologi dan pengetahuan telah mengalami kemajuan yang menakjubkan meskipun masih memerlukan kepada pencerahan dan penyeimbangan, di mana agama dan sains perlu bersinergi dalam merumuskan kaedah penyelesaian terhadap perkara yang berkaitan dengan psikologi umat. Vicktor E Frankl menawarkan teori logoterapi untuk memperolehi the meaningfull life (kehidupan yang bermakna). Logoterapi adalah sebuah teori yang mendeskripsikan potensi rohani sebagai elemen penting bagi mengatasi kemurungan, kerisauan dan tekanan mental. Malik B. Badri memuji Vicktor E. Frankl sebagai logoterapis yang menggunakan psikologi yang optimistik bersesuaian dengan prinsipprinsip kemanusiaan (humanism) dalam mencapai kehidupan yang bermakna. ${ }^{3}$

\section{Kaunseling sebuah Terminologi}

Kaunseling merupakan satu bahagian daripada psikologi. Kaunseling adalah suatu usaha untuk memberi bantuan dan khidmat kepada klien yang mengalami masalah dalam kehidupan. Perkataan 'kaunseling' mencakupi makna bekerja dengan ramai orang dan hubungan yang memungkinkan pemecahan sesuatu masalah. Kaunseling juga adalah suatu usaha untuk memberikan kesempatan dan ruang kepada klien bagi mengekplorasi, menemui dan

\footnotetext{
${ }^{3}$ Malik B. Badri, Dilema Psikolog Muslim, terj. Siti Zainab (Jakarta: Pustaka Firdaus, 1979), 74.
} 
menjelaskan cara hidup yang lebih memuaskan dan cerdas dalam menghadapi sesuatu perkara atau situasi.

Kaunseling menghuraikan hubungan profesional di antara kaunselor dengan klien. Lazimnya, hubungan ini membabitkan satu individu atau lebih individu dengan lainnya. Pada prinsipnya, kaunseling merupakan usaha bagi menolong klien supaya memahami dan menghuraikan pandangan mereka terhadap kehidupan, membantu memperolehi matlamat diri (selfdetermination) melalui keterangan yang telah dimaklumkan dengan baik dan penyelesaian masalah emosi atau karakter interpersonal. ${ }^{4}$

Kaunseling mempunyai hubungan yang rapat dalam apa jua bidang kehidupan manusia termasuk pada era moden. Kemajuan moden sebenarnya bertujuan untuk memberi kesenangan dan mempercepatkan aktiviti dan proses dalam kehidupan. Namun elemen-elemen fitrah dan kemanusiaan sering diketepikan oleh individu dan masyarakat. Kegagalan melihat fitrah manusia telah mengundang pelbagai masalah yang pada hakikatnya adalah suatu dugaan dan cabaran hidup sehingga menyebabkan manusia menghadapinya dengan penuh kebimbangan dan keresahan hati. Pada suatu peringkat kebuntuan berfikir untuk cuba memahami dan mengatasi dugaan dan cabaran tersebut, maka manusia mula mengalami kecelaruan minda. Akhirnya individu dan masyarakat lebih melihat dan menerima kepelbagaian fenomena sebagai lumrah kehidupan sehingga fitrah manusia terus terabai. ${ }^{5}$

Kaunseling Islam adalah suatu proses khidmat dan bantuan bagi individu supaya menyedari bahawa mereka

\footnotetext{
${ }^{4}$ John McLeod, An Introduction in Counselling, terj. A. K. Anwar (Jakarta: Kencana, 2008), 7.

${ }^{5}$ Rosinah Ali, "Kaunseling Spiritual: Pendekatan Terbaik Menangani Permasalahan Hidup" (makalah, Prosiding Seminar International Konseling Malindo, Padang, Indonesia, 13-15 November 2012, 302.
} 
adalah makhluk ciptaan Tuhan yang bertanggungjawab bagi dirinya sendiri yang semestinya beribadah kepada Allah SWT sesuai dengan tujuan penciptaannya di muka bumi ini. Apabila tingkat kesedaran individu meningkat, maka aktiviti apapun yang dikerjakan, maka ia mampu memberikan manfaat yang positif, seperti memperolehi kebahagiaan dan ketenangan. ${ }^{6}$

Kaunseling Islam merupakan bantuan terarah daripada seorang kaunselor terhadap klien yang menghadapi masalah, sehingga klien tersebut boleh menjalani hidup dengan lebih baik dan bahagia sesuai dengan panduan dan petunjuk al-Qur'an dan al-Sunnah. Oleh itu, Kaunseling Islam dapat diformulasikan sebagai suatu usaha untuk meningkatkan kesedaran individu bagi meraih kebahagiaan hidup di dunia dan juga di akhirat.

Proses kaunseling Islam, pada mulanya dikenali dengan terma hisbah atau ihtisab. Kaunselornya disebut juga dengan muhtasib, sedangkan klien disebut muhtasab 'alayh. Hisbah bererti menyuruh klien melakukan perbuatan baik yang sebelumnya ditinggalkan dan melarang melakukan perbuatan munkar yang sebelumnya dikerjakan. Kaunselor juga bertindak sebagai pendamai di antara klien yang saling bermusuhan dan berbantahan. ${ }^{7}$

Kaunseling Barat mahupun kaunseling Islam telah pun memberikan sumbangan bagi penyelesaian masalah yang dihadapi klien. Para pengkaji kaunseling Barat setakat ini sudah banyak menjalankan kajian ilmiah dengan menggunakan pendekatan teori dan praktikal seperti mana yang sedia dimaklumi, antaranya ialah psikoanalitik, eksistensial humanistik dan behavioristik. ${ }^{8}$ Berbeza dengan kaunseling Barat, ajaran Islam yang

6 Tohari Musnamar et al., Dasar-Dasar Konseptual Bimbingan dan Konseling Islami (Yogyakarta: UII Press, 1992), 5.

${ }^{7}$ Ahmad Mubarok, Konseling Agama Teori dan Kasus (Jakarta: Bina Rena Pariwara, 2000), 79.

${ }^{8}$ Gerald Corey, Theory and Practice of Counseling and Psychotherapy, terj. E. Koswara (Jakarta: Refika, 1997), vii. 
terkandung dalam intisari sumber utama iaitu al-Qur'an dan al-Sunnah telah sedia menawarkan metodologi dan pendekatan dalam menyelesaikan masalah umat yang antara lainnya boleh direalisasikan melalui pendekatan kaunseling Islam.

Perkara yang berkaitan dengan kesihatan jiwa, spiritual, emosi dan mental seperti gangguan mental, stres dan murung yang membabitkan individu, ahli keluarga dan masyarakat sudah sampai ke tahap yang membimbangkan hasil dari gaya hidup yang tidak sihat pada masa kini. Bagi mengatasi hal seperti ini, kaunseling Islam adalah alternatif yang boleh dijadikan paradigma baru dalam kaunseling, di mana al-Qur'an dan al-Sunnah dijadikan sebagai asas pengaplikasiannya. Atau dengan kata lain, kaunseling Islam adalah sebuah paradigma dan tawaran Islam bagi memberi bantuan kepada klien melalui pendekatan al-Qur'an mahupun al-Sunnah. Al-Qur'an dan al-Sunnah adalah sumber mutlak ajaran Islam yang menjadi penyejuk hati yang gundah gulana dan pengubat hati yang berkecai. ${ }^{9}$

Kaunseling Islam dengan konsepnya yang menyeluruh telah teruji semenjak kerasulan Muhammad SAW, yang kini penggunaan dan pengaplikasiannya perlu digalakkan lagi. Kecenderungan kaunselor dalam mengadaptasi pemikiran sekular, kenyataannya berbalik menuju konsep baku iaitu menggunakan kandungan Islam sebagai metodologi dan praktis kaunseling. Dengan menggunakan kaunseling Islam sebagai sebuah metodologi dan praktis diharapkan boleh memberikan suatu suntikan baru bagi menjamin kehidupan yang selesa, cermat dan bahagia di dunia dan di akhirat.

\footnotetext{
9 Allah SWT berfirman yang bermksud: "Hai manusia, sesungguhnya telah datang kepadamu pengajaran daripada Tuhanmu dan penyembuh bagi penyakit-penyakit (yang berada) dalam dada dan petunjuk serta rahmat bagi orang-orang yang beriman”. Yunus 10:57.
} 


\section{Manusia dalam Perspektif Kaunseling}

Manusia adalah makhluk Tuhan yang paling sempurna. Manusia dibekali dua potensi yang memiliki kecenderungan untuk berperilaku buruk ataupun baik. ${ }^{10}$ Dalam penyempurnaan diri, manusia memerlukan rasioemosional. Rasio-emosional membekal, mengarah, membimbing dan mendorong perilaku positif mahupun negatif.

Psikoanalitik merupakan sebuah model instrumen yang menganggap libido seks sebagai sebuah model perkembangan keperibadian manusia dan suatu energi psikologi yang dinamik dalam perkembangan peradaban. Manusia pada asasnya boleh dikendalikan oleh nalurinaluri yang bermatlamat bagi mencari kepuasan dan keselesaan. Apabila naluri-naluri ini tidak dikendalikan, maka ia boleh mempengaruhi kehidupan, sama ada bersifat anti sosial mahupun menjadi barbarism (ganas) dan anarkis. Manusia juga tidak boleh sepenuhnya menekan kemahuan dan hasrat bagi memperolehi kepuasaan dan keselesaan. Manusia dihadapkan kepada dua pilihan; antara kemahuan untuk memenuhi kesenangan (pleasure principle) dan kenyataan yang tidak boleh dielakkan. ${ }^{11}$

Psikoanalitik menggunakan beberapa pendekatan kaunseling (counseling approach) dalam menangani klien, iaitu: teknik asosiasi bebas, teknik pentafsiran (interpretation technically), teknik analisis mimpi, teknik analisis atas resistensi dan teknik transferensi. Dalam teknik asosiasi bebas, psikoanalis meminta kepada klien agar membersihkan fikirannya daripada pemikiranpemikiran dan renungan-renungan sehari-hari,

${ }^{10}$ Allah SWT berfirman yang bermaksud: "Serta mengilhamkannya (untuk mengenal) jalan yang membawanya kepada kejahatan, dan yang membawanya kepada bertaqwa". Al-Syams 91:8.

${ }_{11}$ Allen A Bergin, "Psikoterapi dan Nilai-nilai Religius", Jurnal Ilmu dan Kebudayaan Ulumul Qur'an V, no. 4 (1994), 48. 
membenarkannya untuk mengatakan apa sahaja yang terlintas dalam pemikirannya, walaupun menyakitkan. Dalam proses kaunseling psikoanalitik tidak boleh ada satu pun yang disembunyikan klien daripada kaunselor. Klien menyampaikan semua bentuk pemikiran dan perasaan dengan bebas. Sementara kaunselor mesti bersama dalam posisi siap sedia menerima keluhan dan mendengar masalah yang dihadapi klien. Pada pendekatan asosiasi bebas, kaunselor menghurai kembali pengalaman masa lalu klien, kemudian menghilangkan emosi-emosi yang berkenaan dengan aspek-aspek yang mendatangkan trauma yang dihidapinya di masa lalu. Psikoanalitik menamakan proses ini sebagai katharsis. Katharsis ini adalah suatu bentuk pelampiasan emosi daripada pengalaman-pengalaman masa lalu yang menyakitkan. Proses ini mendorong klien menyalurkan perasaanperasaan yang terpendam. ${ }^{11}$

Dalam psikoanalitik, pentafsiran adalah sebuah teknik analisis tentang asosiasi bebas, pentafsiran mimpi, resistensi dan tranferensi. Teknik ini berupaya memberikan makna-makna terhadap perilaku sebagai implementasi daripada asosiasi bebas, mimpi, resistensi dan transferensi. Proses ini bertujuan mempercepat proses menumbuh-kembangkan asimilasi dan penyingkapan ketidaksedaran. Bagi psikoanalis, pengakuan adalah faktor penyebab yang menjustifikasi aspek-aspek yang tersembunyi di dalam ketidaksedaran yang boleh diketahui dan dibawa ke proses kesedaran, maka klien dengan sendirinya akan pulih dan lebih baik. ${ }^{12}$

Pendekatan selanjutnya, psikoanalitik menggunakan analisis mimpi yang merupakan proses dalam penyingkapan dimensi yang berhubungan dengan mimpimimpi yang dialami selama klien tertidur. Mimpi dalam

\footnotetext{
${ }^{11}$ Corey, Theory and Practice of Counseling and Psychotherapy, 41.

${ }^{12}$ Sarlito W. Wirawan, Berkenalan dengan Aliran-Aliran dan TokohTokoh Psikologi (Jakarta: Bulan Bintang, 2002), 162.
} 
psikoanalitik adalah transperansi bayangan atau cerita simbolik daripada perilaku masa lalu yang tidak terungkap. Melalui mimpi, seorang kaunselor dapat memahami makna-makna yang tersembunyi. Dalam menganalisis mimpi-mimpi ini, mimpi-mimpi tersebut mesti diceritakan secara langsung oleh klien dan bukan didengar daripada orang lain. Proses cerita klien secara langsung ini bertujuan bagi menghindarkan manipulasi fakta dalam mencari simbol-simbol yang ada dalam mimpi-mimpi klien. Pada prinsipnya, makna daripada mimpi itu hanya diketahui oleh klien, namun ia tidak menyedari sepenuhnya pentafsiran daripada mimpinya itu. $^{13}$

Langkah yang paling penting dalam proses kaunseling psikoanalitik adalah pendekatan melalui pentafsiran pertahanan (resistensi). Pentafsiran pertahanan adalah suatu proses bagi memarginalkan dan mengenepikan daya pertahanan yang melawan kelangsungan proses bimbingan. Teknik pentafsiran berupaya mencegah klien daripada mengemukakan bahan kajian yang tidak dikehendaki. Pertahanan adalah sebuah dinamika tidak sedar yang digunakan oleh klien sebagai mekanisme pertahanan (defense mechanic) terhadap kegelisahan yang menghambat dan menjadi penghalang dalam proses pemulihan. Apabila mekanisme pertahanan ini tidak prosedural, maka kemungkinan besar klien tidak boleh dipulihkan dengan maksima. Sebaliknya, apabila pentafsiran boleh dilakukan secara prosedural terhadap pertahanan tersebut, maka klien boleh bekerjasama dengan kaunselor untuk memulihkan masalah gangguan mental yang dihidapinya. ${ }^{14}$

${ }^{13}$ Berrnard Poduska, Empat Teori Kepribadian (Jakarta: Restu Agung, 1990), 87.

14 Khairunnas Rajab, Agama Kebahagiaan (Yogyakarta: Pustaka Pesantren, 2012), 65. 
Pendekatan lain dalam prosedur psikoanalitik adalah transferensi. Transferensi adalah perilaku perlawanan yang dicipta klien dengan sendirinya kerana ia tidak memperolehi jawapan bagi masalah-masalah yang dihidapinya. Transferensi adalah teknik utama yang mendorong klien bagi menghidupkan kembali masa lalu yang lenyap. Transferensi sangat memungkinkan klien memperolehi pemahaman terhadap sifat, angan-angan, khayalan-khayalan dan boleh pula memberi pemahaman berkenaan masa lalu. Transferensi juga membuka peluang bagi menembus konflik-konflik masa lalu yang sentiasa dipertahankan hingga sekarang yang boleh mengganggu pertumbuhan emosional. ${ }^{15}$

Berbeza dengan psikoanalitik, kaunseling humanistik memandang manusia sebagai makhluk yang menentukan diri, yang bererti bahawa ia memiliki kebebasan untuk memilih keperluan-keperluan dalam hidupnya. Manusia pada dasarnya ingin bebas dan bertanggungjawab atas pandangan hidup dan menentukan takdirnya sendiri. ${ }^{16}$ Individu dipengaruhi oleh keinginan peribadi yang dihubungkan kepada pengalaman-pengalaman mereka sendiri. ${ }^{17}$

Maslow, pelopor humanistik melihat manusia sebagai universal, dulu, kini dan akan datang. Pada prinsipnya individu berperilaku didorong oleh motif-motif keperluan yang mesti diperolehinya. Seorang individu yang tidak boleh memenuhi keperluan-keperluan hidupnya, seringkali menghidapi kekhuatiran diri, kegoncangan diri dan penyakit mental. Keperluan yang tidak dapat dipenuhinya akan melahirkan kegoncangan seperti kekurangan vitamin dan kekurangan sulfur amonia. ${ }^{18}$

${ }^{15}$ Corey, Theory and Practice of Counseling and Psychotherapy, 43.

${ }^{16}$ Ibid., 68.

${ }^{17}$ Wasty Soemanto, Psikologi Pendidikan: Landasan Kerja Pemimpin Pendidikan (Jakarta: Rineka Cipta, 1998), 136.

${ }^{18}$ Hasan Langgulung, Teori-Teori Kesehatan Mental (Jakarta: Pustaka Al-Husna, 1986), 33. 
Sebagai seorang tokoh humanistik, Maslow sentiasa menghubungkan masalah pemenuhan keperluan kepada motif, sebab musabab yang menjadi tuntutan hidupnya. Motif atau motivasi boleh menunjukkan kepada masalah dalam diri individu yang berasaskan kepada sebabmusabab suatu keperluan. Motif ini juga yang memjadikan individu aktif dan menumbuh-kembangkan perilaku yang lazim dalam pemenuhan keperluan hidupnya. ${ }^{19}$

Maslow memfokuskan kepada aspek diri manusia yang memiliki naluri azali yang baik dan mempunyai keinginan untuk mencapai kesempurnaan diri. Apabila keadaan lingkungan menghalang atau mengganggu perkembangan psikologinya, maka individu tersebut akan berkembang secara neurotik. Kondisi ini boleh berlaku disebabkan naluri dalam diri manusia lemah dan mudah dipengaruhi oleh faktor lingkungannya. ${ }^{20}$

Individu yang beraktualisasi diri dipandang penting berhubungan dengan orang lain. Individu menggunakan seluruh kemampuannya supaya dipandang masyarakat persekitarannya sebagai individu yang aktual. Individu yang beraktualisasi diri mesti menyedari, kekuatan mahupun kelemahannya. Apabila sebaik sahaja individu memikirkan kekuatan dirinya, maka ia boleh berlaku sebagai 'super'; sedangkan seseorang 'super' sukar untuk mencintai ataupun sukar untuk didekati. Dengan menunjukkan kelemahan diri, individu lebih berperilaku sebagai manusia sebenar yang mudah didekati. ${ }^{21}$

Penyakit psikologi dan mental sangat mudah menghinggapi manusia disebabkan oleh keperluankeperluan nalurinya yang tidak dipenuhi. Seringkali manusia merasakan gangguan psikologi dan mental kerana

${ }^{19}$ Linda L Davidoff, Introduction to Psychology (New York: Mc Graw-Hill Inc, 1981), 4.

${ }^{20}$ Azlina Abu Bakar, Psikologi Personaliti Individu (Selangor: Karisma Publications Sdn Bhd, 2002), 89.

${ }^{21}$ Poduska, Empat Teori Kepribadian, 150. 
tidak mampu menjalin hubungan sesama manusia secara baik. Maslow mempunyai pengalaman dalam menangani masalah kesihatan jiwa. Pengalaman, menurut Maslow, dapat menghilangkan rasa gelisah dan rasa cemas melalui cara yang tidak diketahui.

Rasa gelisah merupakan fenomenologi rasa takut terhadap masa depan dan persoalan-persoalan yang terkandung pada masa depan yang menyatakan eksistensi manusia dan kemanusiaan seorang individu. ${ }^{23}$ Kesedaran terhadap kebebasan dan tanggungjawab adalah suatu sifat dasar yang ada pada manusia dan dapat menimbulkan rasa gelisah. Kegelisahan yang terdapat pada diri individu, berkemungkinan disebabkan kesedaran terhadap keterbatasan dan kemungkinan tidak mampu menghindarkan diri daripada kematian. Kesedaran terhadap kematian mempunyai erti penting bagi kehidupan individu, kerana kesedaran tersebut menghadapkan individu pada realiti bahawa ia hanya memiliki waktu yang sangat terbatas untuk mengaktualkan potensipotensinya.

Selain itu, dosa juga merupakan penyumbang kepada keadaan diri manusia, kerana ia adalah akibat daripada kegagalan individu untuk betul-betul menjadi seseorang yang sesuai dengan kesanggupannya. ${ }^{24}$ Dosa merupakan masalah yang dapat mendatangkan rasa gelisah, cemas, dan ketidakselesaan. Individu yang gagal memberi tindak balas kepada rasa berdosa, atau menolak rasa itu, maka ia akan memperkukuh kegoncangan psikologi. Bagi Maslow, klien dalam proses pembimbingan mesti membuang rasa takut, perasaan berdosa dan kegundahan yang dihidapinya. $^{25}$

\footnotetext{
${ }^{22}$ Jerry M. Berger, Personality (USA: Wordsworth Thomson Learning, 2000), 325.

${ }^{23}$ Hasan Langgulung, Teori-Teori Kesehatan Mental, 137.

${ }^{24}$ Corey, Theory and Practice of Counseling and Psychotherapy, 55.

${ }^{25}$ Ibid., 60.
} 
Berbeza dengan psikoanalitik dan humanistik; behavioristik memandang perilaku manusia sebagai sebuah pelaziman operan (operant conditioning). Behavioristik mempunyai teknik perilaku yang spesifik. Behavioristik menunjukkan suatu hal yang efektif melalui alat-alat yang objektif dan mesti ada usaha yang bersinergi sebagai langkah penambahbaikan. Aliran ini menggunakan beberapa prosedur ataupun teknik yang dilalui kaunselor dalam proses pembimbingan klien, di antaranya; desensitisasi sistematik, impulsif, latihan asertif, aversi, pelaziman operan, penguatan positif, pembentukan respons, penguatan intermiten, pemadaman dan percontohan. ${ }^{26}$

Pelaziman operan merupakan suatu usaha yang dilakukan oleh seorang klien di mana ianya berada dalam keadaan sedar. Proses ini merupakan asas daripada asosiasi, iaitu suatu hubungan antara stimulus dengan respons yang wujud kerana hubungan refleks. ${ }^{27}$ Perilaku operan adalah perilaku yang muncul, yang kemudian menjadikannya sebagai watak organisme yang aktif. Perilaku operan seutuhnya mengandungi ruang aktiviti seseorang individu dalam hidup dan kehidupannya. ${ }^{28}$

Pemadaman (extinction) adalah suatu respons yang terjadi secara terus menerus tanpa penguatan. Modelmodel perilaku yang dipelajari cenderung melemah dan dipadamkan oleh individu yang berada dalam proses kaunseling. Teknik pemadaman adalah prosedur yang berimplikasi pada pemadaman perilaku yang maladaptif (perilaku menyimpang). Biasanya teknik pemadaman ini mengambil masa yang panjang kerana perilaku tersebut telah berproses, sehingga ia telah bersepadu dengan

\footnotetext{
${ }^{26}$ Khairunnas Rajab, Pengubatan Jiwa (Kuala Lumpur: Darul Fikir, 2012), 98.

${ }^{27}$ Poduska, Empat Teori Kepribadian, 43.

${ }^{28}$ Khairunnas, Pengubatan Jiwa, 99.
} 
dirinya. ${ }^{29}$ Namun, melalui proses pemadaman ini, perilaku itu akan hilang secara semula jadi.

Penguatan positif mahupun negatif adalah prosedur yang diyakini sebagai pembekal bagi individu dalam berperilaku positif mahupun negatif. Menurut Mc. Dougall, perilaku individu mempunyai sifat kebebasan (indeterminism) iaitu bebas memilih arah dan tujuannya sendiri. Kebebasan ini bertentangan dengan pendapat behaviorisme yang menganggap kepelbagaian tujuan perilaku manusia merupakan sesuatu yang tidak disengaja atau kebetulan dan bahawa perilaku mempunyai unsur bawaan yang disebut sebagai naluri. ${ }^{30}$

Teknik aversi digunakan bagi menghilangkan gangguan-gangguan perilaku khas yang melibatkan asosiasi perilaku yang simtomatik dengan stimulus yang menyakitkan sehingga perilaku yang tidak diingini tidak muncul lagi. Stimulus-stimulus aversi berupa hukuman dengan kejutan elektrik atau ramuan ubat-ubatan yang membuat perut terasa mual. Teknik aversi adalah teknik yang kontroversi dalam kalangan behavioris, namun ia sering digunakan untuk tujuan pemusatan. ${ }^{31}$

Behavioris Watson melihat perilaku manusia yang sarat dengan pengaruh daripada faktor persekitaran dan mempercayai bahawa perilaku tersebut merupakan implementasi daripada pembelajaran. ${ }^{32}$ Watson meyakini bahawa setiap struktur dan refleks seperti emosi ketakutan, kemarahan dan kasih sayang diwarisi oleh manusia sejak lahir. ${ }^{33}$ Begitu juga halnya dengan orang dewasa yang mempunyai emosi, rasa benci, bangga,

${ }^{29}$ Corey, Theory and Practice of Counseling and Psychotherapy, 225.

${ }^{30}$ Sarlito, Berkenalan dengan Aliran-Aliran, 113.

${ }^{31}$ Ibid., 220.

${ }^{32}$ Charles Gelso dan Bruce Fretz, Counseling Psychology (New York: Harcourt College Publisher, 2001), 331.

${ }^{33}$ Ibid., 332. 
cemburu dan perasaan malu di mana kesemua perasaan ini adalah bahagian daripada rasa takut, marah dan sayang. ${ }^{34}$

\section{Rumusan tentang Manusia dalam Perspektif Kaunseling}

Masalah yang dihadapi manusia pada dekad ini telah menimbulkan kerisauan dan memerlukan solusi segera. Kesan sains moden dan teknologi maklumat tidak serta merta mengawal perilaku individu untuk sentiasa positif. Setakat ini, perilaku yang ditonjolkan oleh sesetengah individu telah menimbulkan kekhuatiran dalam masyarakat. Fenomena ini ditunjukkan dengan wujudnya individu yang menghidapi tekanan mental, kemurungan, kecemasan dan kegelisahan. Keadaan ini membabitkan individu-individu yang lemah spiritual, rasio-emosional yang belum terarah dan sosio-ekonomi yang tidak kuat.

Masalah yang berkaitan psikologi, secara realitinya telah pula meningkatkan perilaku bunuh diri. Antara sebab-musabab perilaku bunuh diri adalah kerana pemisahan antara manusia dengan agama sebagai implikasi daripada perkembangan falsafah sains Barat. ${ }^{35}$ Keseimbangan antara agama (kerohanian atau spiritual) dan dunia adalah teramat penting. Spiritual adalah sebuah model keseimbangan yang ditawarkan antara nilai-nilai agama dengan nilai-nilai tamadun moden. ${ }^{36}$

Islam melalui metodologi kaunseling Islam diharapkan boleh memberikan solusi terhadap masalah kemanusiaan terutamanya masalah yang berkaitan dengan penyesuaian diri sendiri, individu dengan individu lainnya, masyarakat secara umum dan alam persekitarannya. Dalam usaha penguatan metodologi kaunseling Islam ini, seorang kaunselor mesti merujuk kepada sumber mutlak

\footnotetext{
${ }^{34}$ Ibid., 357.

35 Mahdi al-Ghalsyani, Filsafat Sains menurut al-Qur'an (Bandung: Mizan, 1993), 9.

${ }^{36}$ Akbar S. Ahmed, Post Modernism and Islam: Predicament and Promise (London: Routledge, 1992), 23.
} 
Islam iaitu al-Qur'an dan al-Sunnah. Unsur lain yang mendukung pengaplikasian kaunseling Islam dapat diasaskan kepada wujudnya pemikiran bahawa semua aktiviti klien berorientasikan tauhid, motivasi beribadah, perubahan perilaku individu melalui pelaziman dan model akhlāq al-karimah, serta juga melalui penentuan sekatan sebagai usaha mewujudkan disiplin. ${ }^{37}$

Untuk mencapai matlamat dalam mewujudkan kaunseling Islam secara holistik, maka seorang kaunselor perlu memenuhi beberapa syarat iaitu:

1. Kaunselor Islam semestinya memahami ajaran Islam secara mendalam dan menyeluruh.

2. Kaunselor Islam adalah orang yang mengamalkan nilai-nilai ajaran Islam dengan baik.

3. Kaunselor Islam semestinya mampu memindahkan kaedah-kaedah agama Islam secara garis besar yang relevan dengan masalah yang dihadapi klien.

4. Kaunselor Islam hendaklah menguasai metode dan strategi yang tepat dalam menyampaikan bimbingan dan kaunseling kepada klien, sehingga klien dengan tulus menerima nasihat kaunselor.

5. Kaunselor Islam mesti memiliki peribadi yang terpuji sebagai teladan dalam perilaku baik di tempatnya bekerja mahupun di luar. Dengan kata lain, kaunselor Islam memiliki keperibadian yang mulia atau sebagai uswah al-hasanah.

6. Kaunselor Islam hendaklah menguasai bidang psikologi secara integral, sehingga dalam melaksanakan bimbingan kaunseling akan dengan mudah menyampaikan nasihat dengan pendekatan psikologi. $^{38}$

37 Abdul Choliq Dahlan dalam Diskusi Forum Doktor Universitas Islam Sultan Agung (UNISSULA), diadakan pada 23 Mac 2007.

38 Syamsul Munir Amin, Bimbingan dan Konseling Islam (Jakarta: Amzah, 2010), 270. 
Secara fitrah manusia memiliki potensi untuk mengenal dan beriman kepada Allah, iaitu bertauhid, mendekatkan diri kepada-Nya, kembali kepada-Nya, dan meminta pertolongan kepada-Nya. ${ }^{39}$ Dalam proses penyelenggaraan kaunseling Islam, seorang kaunselor bertanggungjawab membimbing kliennya menuju tauhid yang benar, berkeyakinan tentang kekuasaan-Nya, dan berkeyakinan bahawa Allah adalah tempat memohon bantuan dan pertolongan. Apabila proses kaunseling ini berlangsung dengan efisien, maka klien bermasalah dengan potensi fitrah yang dimilikinya mampu memposisikan dirinya ke suatu solusi yang memberi manfaat terhadap dirinya kerana akibat dan tanggungjawabnya sendiri dalam berbuat sesuatu.

Manusia lahir ke bumi dalam keadaan fitrah yang suci bersih, namun ia kemudiannya dipengaruhi oleh sejumlah faktor yang antara lainnya ialah faktor keluarga dan lingkungan sosialnya, sehingga ia memiliki kesedaran beragama, bermotivasi, berakhlak dan bergaul secara sosial, budaya, politik serta berekonomi. Rasulullah SAW menjelaskan dalam sabdanya yang bermaksud: "Tidak seorang bayipun yang lahir kecuali ia lahir berdasarkan fitrah (suci), lantas kedua orang tuanyalah yang menjadikannya seorang Yahudi, Kristian mahupun Majusi. $^{40}$

Dalam mencapai kehidupan yang lebih baik manusia memiliki motivasi, di antaranya ialah motivasi fisiologi, motivasi untuk memperolehi keamanan, motivasi aktualisasi atau eksistensi diri, motivasi untuk mempertahankan hidup serta motivasi untuk menghindarkan diri daripada rasa lapar dan takut yang

39 Muhammad 'Uthmān Najātī, al-Hadìth al-Nabawiyyah wa 'Ilm alNafs (Kaherah: Dār al-Shuruq, 2000), 36.

40 Muḥammad ibn Ismā'ìl Abū 'Abd Allāh al-Bukhārī, Șaḥih alBukhārì 1, Kitāb al-Janāìz, no. 1296 (Beirut: Dār al-Fikr, 1981), 104. 
merupakan sebahagian daripada keperluan hidup yang mesti diusahakannya. Allah Ta'ala menghuraikan perkara ini dalam firman-Nya yang bermaksud:

"Dan sungguh akan Kami berikan cubaan kepadamu, dengan sedikit ketakutan, kelaparan, kekurangan harta, jiwa dan buahbuahan. Dan berikanlah berita gembira kepada orang-orang yang sabar".

\section{Al-Baqarah 2:155}

Allah telah membuat suatu perumpamaan (dengan) sebuah negeri yang dahulunya aman lagi tenteram, rezekinya datang kepadanya melimpah ruah dari segenap tempat, tetapi penduduknya telah mengingkari nikmatnikmat Allah tersebut. Oleh kerana itu, Allah telah merasakan kepada mereka kelaparan dan ketakutan disebabkan apa yang mereka telah lakukan". ${ }^{2}$

Motivasi fisiologi adalah motivasi bagi memperolehi makan dan minum. Rasa lapar dan haus mempengaruhi kondisi fizikal dan psikologikal individu. Rasa lapar menimbulkan perasaan lelah, penat dan letih. Apabila individu merasakan kelaparan, maka perasaan risau, takut dan cemas boleh membuatnya mengalami gangguan psikologi yang hebat.

Di samping motivasi fisiologi, motivasi bagi memperolehi rasa aman adalah penting. Rasa aman adalah sesuatu yang mutlak diinginkan seorang individu. Apabila rasa aman tidak boleh diperolehi, maka seorang individu merasa ketakutan. Perasaan takut adalah bahagian lain yang boleh menimbulkan perasaan gelisah dan risau. ${ }^{43}$

Motivasi aktualisasi diri adalah motivasi individu bagi menunjukkan keadaan dirinya kepada persekitarannya. Motivasi aktualisasi diri atau eksistensial diri adalah usaha individu untuk memperolehi pengakuan

\footnotetext{
${ }^{42}$ Surah al-Nahl 16:112.

${ }^{43}$ Najāti, al-Hadìth al-Nabawiyyah wa Ylm al-Nafs, 28.
} 
yang menunjukkan ia boleh melakukan sesuatu yang lebih baik. Seorang individu ingin menunjukkan kelebihan dan kemajuan yang telah dicapainya. Dalam kaunseling, aktualisasi diri boleh diterima sebagai usaha pemberdayaan individu bahawa ia mempunyai kemampuan dan kesanggupan yang baik.

Kaunseling Islam memandang individu sebagai subjek yang menghendaki keperluan-keperluan yang tidak boleh diabaikan. Apabila keperluan-keperluan individu ini diabaikan dan diketepikan, maka masalah-masalah baru akan sentiasa muncul bersilih ganti. Kaunseling Islam adalah sebuah model yang mengintegrasikan ajaran Islam dengan psikologi. Dalam kaunseling Islam, ajaran berkenaan iman, takwa, ihsan, istiqamah, kejujuran, keseimbangan, dan keterbukaan adalah sesuatu yang mutlak dan merupakan asas dalam pengaplikasiannya.

Kaunselor Islam semestinya memberikan pengetahuan tentang iman. Seorang individu wajib meyakini Allah dengan hati, berikrar dengan lisan, beribadah konkrit sesuai dengan syariat. Iman adalah suatu terma yang menghuraikan bahawa Allah SWT adalah tumpuan penyembahan mutlak dan menyekutukanNya adalah haram. Keimanan adalah implementasi daripada frasa Là ilāha illa Allāh. Seorang individu yang mengucapkan Là ilāha illa Allāh maka ketika itu ia seakan-akan mengatakan tidak ada lagi tempat mencari ketenangan, tidak ada lagi tempat meminta pertolongan, tidak ada lagi yang dicintai, tidak ada lagi yang disembah, tidak ada lagi pemilik, tidak ada lagi yang ditaati, tidak ada lagi yang diagungkan dan tidak ada lagi yang dijadikan tempat berpegang serta tidak ada lagi yang menguasai kecuali Allah Ta'ala. ${ }^{44}$

Kaunselor muslim perlu meyakinkan klien bahawa masalah yang dihadapinya boleh diselesaikan dengan optimistik melalui prinsip-prinsip asasi yang diperolehi

${ }^{44}$ Said Hawwa, al-Islam (Jakarta: Gema Insani Press, 2004), 39. 
daripada aspek-aspek yang wujud dalam keimanan. Tambahan pula, dengan prinsip asasi bahawa Allah adalah sumber keagungan yang mengabulkan doa-doa hambaNya yang secara berterusan meminta kepada-Nya dengan penuh keikhlasan. ${ }^{45}$

Kaunselor muslim perlu menghuraikan kepada klien, bahawa dua kalimat syahadat iaitu Ashhadu an lā ilāha illa Allāh wa ashhadu anna Muhammad al-rasūlullāh mampu menghilangkan dan membebaskan diri daripada segala belenggu atau dominasi tuhan-tuhan temporal dan relatif, seperti material dan hawa nafsu. ${ }^{46}$

Selepas menghuraikan iman, kaunselor muslim perlu pula menanamkan nilai-nilai ketakwaan kepada klien. Ketakwaan adalah terminologi yang boleh membebaskan seorang individu daripada perilaku maksiat. Individu yang bertakwa adalah seseorang yang sentiasa menjaga hati dan jiwanya supaya dekat dengan Allah. ${ }^{47}$ Semakin individu bertakwa kepada Tuhannya, sebaik itu pula ia hidup dalam kesihatan mental. ${ }^{48}$

Individu yang bertakwa selalunya mengiringi perbuatannya dengan ihsān. Keimanan dan ketakwaan seseorang individu belum sempurna sehinggalah ia mengiringinya dengan perilaku iḥsān. Perilaku ih̆sān adalah mentauhidkan Allah secara murni, menyifati-Nya dengan semua kesempurnaan dan membersihkan-Nya daripada segala kekurangan. Perilaku iḥsān iaitu mengerjakan ibadah dengan sempurna, memenuhi syarat dan rukun, serta ikhlas dalam mengerjakannya. Ih $h \bar{a} \bar{n}$

${ }^{45}$ Ibnu Taimiyyah, al-Ubudiyah (Surabaya: Bina Ilmu, t.t.), 74.

46 Abdul Mujib, Fitrah dan Kepribadian Islam: Sebuah Pendekatan Psikologis (Jakarta: Darul Falah, 1999), 197.

47 Syaikh Mahmud Al-Mishri, Rihlah ila al-Darul Akhirat, terj. Ghilmanul Wasath (Jakarta: Al-Kautsar, 2014), 56.

48 Zakiah Darajat, Kesehatan Mental: Peranannya dalam Pendidikan dan Pengajaran (Jakarta: IAIN, 1984), 4; Khairunnas Rajab, Konflik Politik Selatan Thailand: Efek Psikologis Melayu Muslimah (Yogyakarta: Aswaja Pressindo, 2015), 29. 
termeterai apabila seseorang beribadah kepada Allah, seakan-akan ia melihat-Nya. Apabila ia tidak melihat-Nya, sesungguhnya ia merasakan bahawa Allah Maha Melihatnya. ${ }^{49}$

Kaunselor muslim pada tahapan ihsān perlu memberikan motivasi yang kuat dan positif sehingga klien terdorong untuk berakidah dan beribadah secara benar dan sesuai dengan syariat Islam. Berperilaku iḥsān boleh membuka ruang pintu taubat di mana klien terus menerus melakukan ibadah dengan khusyuk. Perasaan individu yang terlepas daripada dosa boleh membawanya kepada ketenangan jiwa. Taubat adalah salah satu cara yang boleh mengeluarkan individu daripada kesulitan dan kegundahan. $^{50}$

Dalam kaunseling Islam, istiqamah adalah salah satu prinsip penting yang mesti dimiliki sama ada oleh kaunselor mahupun klien. Istiqamah adalah tahap yang boleh menjadikan urusan-urusan seseorang menjadi baik, sempurna dan memungkinkannya untuk mencapai manfaat-manfaat yang sentiasa teratur. ${ }^{51}$ Istiqamah dalam kaunseling Islam adalah suatu hasil dan komitmen kaunselor bersama klien untuk saling konsisten dalam menyimpan rahsia, saling terbuka dan saling memahami dalam satu tujuan iaitu untuk meringan dan melepaskan klien daripada derita masalah yang dihadapinya.

Kaunseling Islam juga menetapkan prinsip kejujuran dalam proses pengaplikasian kaunseling. Kejujuran adalah suatu sikap diri yang menjadi tiang penyokong bahawa semua masalah boleh diselesaikan. Sifat jujur adalah sifat mulia yang dapat menghalang seseorang individu daripada

${ }^{49}$ Musthafa Muhammad al-Thair, Aqbasun min Nuril Haq, terj. Subhan Nur (Jakarta: Qisthi Press, 2004), 65.

50 Abu Hasan, Manal, Sabil al-Taaibaat, terj. Muhammad Hikam (Jakarta: Cakrawala, 2008), 386.

51 Al-Qusyairy al-Naishaburi, Risalah al-Qusyairiyyah fi ilmi alTashawwuf, terj. Muhammad Lukman Hakim (Surabaya: Risalah Gusti, 1999), 239. 
berdusta. Seorang sufi, al-Junayd al-Baghdādi menyatakan inti daripada kejujuran adalah seseorang berkata jujur pada suatu keadaan yang apabila ia berkata jujur, maka ia tidak akan selamat kecuali ia berdusta. ${ }^{52}$

Dalam kaunseling Islam, kejujuran teramat penting di mana klien perlu secara jujur menyampaikan masalah yang dihadapinya kepada kaunselor. Klien tidak boleh berdusta kepada kaunselor selama proses kaunseling berlangsung. Kejujuran klien mempermudahkan kaunselor dalam mencarikan pokok dan punca masalah yang dialami klien. Dengan demikian, kaunselor dengan mudah dapat melakukan prognosis dan diagnosis psikologi untuk tujuan terapi terhadap masalah yang dihadapi klien tersebut.

Dimensi kejujuran dalam kaunseling Islam mengandungi asas keterbukaan. Klien semestinya menyampaikan secara terbuka masalah yang di alaminya. Oleh itu, kejujuran dan keterbukaan adalah dua prinsip yang saling melengkapi dalam proses terapi agar masalah yang dihadapi dapat diselesaikan segera.

\section{Kesimpulan}

Kajian Islamisasi ilmu pengetahuan pada beberapa dekad terakhir ini menunjukkan munculnya kajian-kajian optimistik daripada para pakar psikologi muslim dalam usaha mewujudkan psikologi Islam, psikoterapi Islam, kaunseling Islam dan kesihatan mental Islam. Usahausaha ini seterusnya mendapat sambutan daripada para pakar yang lain sehingga menghasilkan pelbagai penerokaan, penemuan dan penghasilan karya secara teori dan pengaplikasian secara praktis. Kaunseling yang merupakan sebahagian daripada bidang psikologi turut diberi keutamaan dalam penerokaan tersebut.

Justeru, artikel ini mengemukakan beberapa elemen penting berasaskan ajaran Islam yang bersumberkan dua sumber utama iaitu al-Qur'an dan al-Sunnah yang perlu

${ }^{52}$ Ibid., 250. 
dikenal pasti, diketahui, dan dipraktiskan sepanjang khidmat dan bantuan klien yang menghadapi masalah. Kaunseling Islam adalah suatu usaha memberikan kesempatan kepada klien bagi mengekplorasi, menemui, dan menjelaskan cara hidup supaya lebih memuaskan dan cerdas dalam menghadapi sesuatu dengan berpaksikan kerohanian atau spiritual keimanan, ketakwaan, peribadatan dan ihssān, istiqamah, kejujuran, keseimbangan dan keterbukaan. Justeru, kaunseling Islam adalah sebuah model yang mengintegrasikan nilai-nilai holistik Islam dengan psikologi.

\section{Rujukan}

Abdul Choliq Dahlan dalam Diskusi Forum Doktor Universitas Islam Sultan Agung (UNISSULA), 23 Mac 2007.

Abdul Mujib. Fitrah dan Kepribadian Islam: Sebuah Pendekatan Psikologis. Jakarta: Darul Falah, 1999.

Abu Hasan, Manal. Meniti Jalan Taubat, terj. Muhammad Hikam. Jakarta: Cakrawala, 2008.

Ahmad Mubarok. Konseling Agama: Teori dan Kasus. Jakarta: Bina Rena Pariwara, 2000.

Ahmed, Akbar S. Post Modernisme and Islam: Predicament and Promise. London: Routledge, 1992.

Azlina Abu Bakar. Psikologi Personaliti Individu. Selangor: Karisma Publications Sdn Bhd, 2002.

Berger, Jerry M. Personality. USA: Wordsworth Thomson Learning, 2000.

Bergin, Allen A., "Psikoterapi dan Nilai-nilai Religius," Jurnal Ilmu dan Kebudayaan Ulumul Qur'an V. no. 4. 1994.

Berrnard Poduska. Empat Teori Kepribadian. Jakarta: Restu Agung, 1990.

Al-Bukhārî, Muhammad ibn Ismā'īl Abū `Abd Allāh, Șahịh al-Bukhārī 1. Kitāb al-Janāiz, no. 1296. Beirut: Dār al-Fikr, 1981. 
Corey, Gerald. Theory and Practice of Counseling and Psychotherapy, terj. E. Koswara. Jakarta: Refika, 1997.

Davidoff, Linda L. Introduction to Psychology. New York: Mc Graw-Hill, Inc, 1981.

Gelso, Charles \& Fretz, Bruce. Counseling Psychology. New York: Harcourt College Publisher, 2001.

Hanna Djumhana Bastaman. Integrasi Psikologi dengan Islam: Menuju Psikologi Islami. Yogyakarta: Pustaka Pelajar, 1997.

Hasan Langgulung. Teori-Teori Kesehatan Mental. Jakarta: Pustaka Al-Husna, 1986.

Hawwa, Said. Al-Islam, terj. Abdul Hayyi al-Kattani. Jakarta: Gema Insani Press, 2004.

Ibnu Taimiyyah. Al-Ubudiyah, terj. Muhammad Hamidy. Surabaya: Bina Ilmu, t.t.

Khairunnas Rajab. Agama Kebahagiaan. Yogyakarta: Pustaka Pesantren, 2012.

Khairunnas Rajab. Konflik Politik Selatan Thailand: Efek Psikologis Melayu Muslimah. Yogyakarta: Aswaja Pressindo, 2015.

Khairunnas Rajab. Pengubatan Jiwa. Kuala Lumpur: Darul Fikir, 2012.

M. Quraish Shihab. Membumikan al-Qur'an, Fungsi dan Peran Wahyu dalam Kehidupan Masyarakat. Bandung: Mizan, 1993.

Mahdi al-Ghalsyani. Filsafat Sains menurut al-Qur'an. Bandung: Mizan, 1993.

Malik B. Badri. Dilema Psikolog Muslim, terj. Siti Zainab. Jakarta: Pustaka Firdaus, 1979.

McLeod, John. An Introduction in Counselling, terj. A. K. Anwar. Jakarta: Kencana, 2008.

Al-Mishri, Syaikh Mahmud. Rihlah ila al-Darul Akhirat, terj. Ghilmanul Wasath. Jakarta: al-Kautsar, 2014.

Najātī, Muhammad 'Uthmān. Al-Hadìth al-Nabawiyyah wa `Ilm al-Nafs. Kaherah: Dār al-Shuruq, 2000. 
Al-Qusyairy al-Naishaburi. Risalah al-Qusyairiyyah fi ilmi al-Tashawwuf, terj. Muhammad Lukman Hakim. Surabaya: Risalah Gusti, 1999.

Sarlito W. Wirawan. Berkenalan dengan Aliran-aliran dan Tokoh-Tokoh Psikologi. Jakarta: Bulan Bintang, 2002.

Al-Thair, Musthafa Muhammad. Percikan Cahaya Ilahi, terj. Subhan Nur. Jakarta: Qisthi Press, 2004.

Tohari Musnamar et al.. Dasar-dasar Konseptual Bimbingan dan Konseling Islami. Yogyakarta: UII Press, 1992.

Wasty Soemanto. Psikologi Pendidikan: Landasan Kerja Pemimpin Pendidikan. Jakarta: Rineka Cipta, 1998.

Zakiah Darajat. Kesehatan Mental: Peranannya dalam Pendidikan dan Pengajaran. Jakarta: IAIN, 1984. 